\title{
Keynes and the dollar in I933: the gold-buying program and exchange rate gyrations
}

\author{
SEBASTIAN EDWARDS \\ University of California, Los Angeles, \\ and National Bureau of Economic Research
}

In December 1933, John Maynard Keyes published an open letter to President Roosevelt, where he wrote: 'The recent gyrations of the dollar have looked to me more like a gold standard on the booze than the ideal managed currency of my dreams.' This was a criticism of the 'gold-buying program' launched in October 1933. In this article I use high-frequency data on the dollar-pound and dollarfranc exchange rates to investigate whether the gyrations of the dollar were unusually high in late 1933. My results show that although volatility was pronounced, it was not higher than during some other periods after I92 I. Moreover, dollar volatility began to subside towards the end of the period alluded to by Keynes.

Keywords: Keynes, gold standard, devaluation, volatility, Roosevelt, Great Depression

JEL classification: $\mathrm{B}_{22}, \mathrm{~B}_{2} \mathrm{I}, \mathrm{B}_{2} 6, \mathrm{E}_{3} \mathrm{I}, \mathrm{F}_{3} \mathrm{I}, \mathrm{N}_{12}, \mathrm{~N}_{22}$

On 3 I December 1933, the New York Times published an open letter from John Maynard Keynes to President Franklin D. Roosevelt. The letter, written at Felix Frankfurter's suggestion, was rather long and touched on many topics related to the economic program of the new US administration. ${ }^{1}$ It opened by stating that

S. Edwards, Anderson Graduate School of Management UCLA, i Io Westwood Plaza, Room C 508, Los Angeles, CA 90095-I48I, USA; email: sebastian.edwards@anderson.ucla.edu. I thank Michael Poyker for his assistance. I have benefitted from conversations with Michael Bordo and Ed Leamer. I am particularly grateful to two referees and to Rui P. Esteves, editor of this journal, for very helpful comments that greatly helped improve the article.

1 There are three versions of the letter. The first one was sent by Felix Frankfurter - a highly respected legal scholar and professor at Harvard, who was eventually appointed to the Supreme Court - to President Roosevelt via diplomatic pouch on I6 December 1933. The second version was published by the New York Times (NYT) on Sunday, 3 I December I933. It was titled 'From Keynes to Roosevelt: Our recovery plan assayed'. The only difference between this version and the one sent by Frankfurter is that the NYT included subtitles. The letter takes almost a full page of the paper. There are two photographs, one of Keynes himself and one of a 'slum clearance', with the caption, 'Public works: the way out?' The third version is shorter, and was published by The Times of London on 2 January I934 (p. I I) under the title, 'Mr Roosevelt's experiments: the dual policies, reconstruction and recovery'. For 
FDR was the 'trustee for those... who seek to mend the evils of our condition by reasoned experiment'. From there, Keynes moved on to argue that there was a significant difference between economic 'recovery' and 'reform'. While both were important, the correct sequencing of policy was recovery-first. In addition, the policies of 'reform' had to be implemented gradually; 'haste will be injurious'. In Keynes's view if 'reform' measures - including the policies of the National Industrial Recovery Act (NIRA) and Agricultural Adjustment Act (AAA) - were pushed too soon and too fast, they would put the policies of recovery in danger; haste would result in a decline in investors' 'confidence'. In the central part of the communication Keynes forcefully argued that recovery had to take place through an increase in aggregate demand, which in turn was to be stimulated through loan-expenditures. Higher prices, he pointed out, should be the result of expanded 'aggregate purchasing power', and not of restricted supply. He also argued that, in terms of monetary policy, the key was to 'reduce the rate of interest on your long-term government bonds to $2 \frac{1}{2}$ per cent or less'.2

Halfway into the missive Keynes addressed the administration's policies on gold and the dollar. He wrote that the 'exchange rate policy of a country should be entirely subservient to the aim of raising output and employment to the right level'. He then added the sentence that many people remember today: 'The recent gyrations of the dollar have looked to me more like a gold standard on the booze than the ideal managed currency of my dreams.'

This was a direct reference to the administration's 'gold-buying program', launched on 25 October $1933 .{ }^{3}$ According to this plan, the Reconstruction Finance Corporation (RFC) was allowed to purchase gold at prices determined periodically by the Secretary of the Treasury and the President. As President Roosevelt explained in his Fourth Fireside Chat, the purpose of this policy was to raise the international price of gold and, in that way, generate a de facto dollar devaluation and, ultimately, higher commodity prices. Almost every day, throughout the program, the price paid by the government exceeded the world price for the metal.

Most analysts interpreted Keynes's words as asserting that during the gold-buying program the dollar exchange rate was excessively volatile, and that this volatility was harmful for the recovery. ${ }^{4}$ Keynes told the President that it was time to make policy changes:

Frankfurter's correspondence with Roosevelt regarding Keynes and other British economists' views on the administration's policies, see Roosevelt (I967, pp. I6I-228).

2 NYT, 3 I December I933, section xx, p. 2. All quotes from the letter in this article are taken from this version (Keynes I933b).

3 As explained below, the gold-buying program was rolled out in two phases. Generally, the second phase, which started in late October, is singled out as 'the gold-buying program'.

4 See Rauchway (2015) for a comprehensive discussion about this period. See Obstfeld and Taylor (2003) for an analysis that places this era in historical context. See Bordo and Sinha (2016) for the Fed's policy during this period. For an analysis of this period see Eichengreen (I992) and Eichengreen and Mitchener (2004). See Mitchener and Weidenmeier (2009) for an analysis of the 
In the field of gold-devaluation and exchange policy the time has come when uncertainty should be ended. This game of blind man's buff with exchange speculators serves no useful purpose and is extremely undignified. It upsets confidence, hinders business decisions, occupies the public attention in a measure far exceeding its real importance, and is responsible both for the irritation and for a certain lack of respect which exists abroad.

Throughout the years, a number of authors have referred to Keynes's open letter. However, there has been no attempt to analyze it in detail, or to use formal statistical techniques to investigate whether the dollar was 'excessively volatile' during the period in question (second half of I933). Harrod (I95 I, pp. 447-8), for example, mentions the open letter within the context of the evolution of Keynes's views on the international monetary system, and points out that his proposals for a new international architecture were summarized in The Means to Prosperity. In the second volume of his biography, Skidelsky (I992, pp. 492-4) provides a more detailed examination of the letter. He discusses its origin and dwells on Keynes's goal in writing it. Skidelsky (p. 493) emphasizes Keynes's criticism of the NRA, a program of reform disguised as recovery that 'should be put into cold storage'. He also points out, briefly, that Keynes believed that it was a mistake to try raising output by depreciating the currency. Moggridge (I992, pp. 580-I) refers to the letter and to Keynes's views on public works and the dollar. He points out that it is unclear whether the missive influenced FDR's policies. Felix (I999, p. 243) refers to the open letter in passing, and mentions that in I933 Keynes was renewing his friendship with Felix Frankfurter.

Many - but by no means all - authors who have analyzed the US abandonment of the gold standard have addressed the letter and its impact. In Ahamed's (2009) book on monetary policy in the interwar period, the antepenultimate chapter is titled 'Gold standard on the booze'. The analysis touches on many policies undertaken during the first year of the Roosevelt administration. However, the letter itself is only mentioned in passing. Sumner (I999, p. 528 and 20I 5, p. 26I) writes about the epistle and argues that it shows that Keynes's concern about inflation was rather high. Rauchway (20 I 5, p. 96) argues that the letter shows that 'Keynes did not seem to understand the political opposition Roosevelt faced.' Dimand (I994, p. 93) deals with the letter briefly when discussing Irving Fisher's proposal for a 'compensated dollar'. Kroszner (I999, p. 9) mentions it in passing in his paper on the abrogation of the gold clauses. Edwards (2017a, p. I9) refers to the letter in his discussion of the intellectual underpinnings of FDR's dollar policy in I933. Some authors, including Galbraith (I984) and O'Connell (20I6), mention the open letter as an early example of Keynes's belief that public works, financed by borrowing, would impact aggregate demand and employment positively. None of these authors, however, undertake an empirical analysis of exchange rate behavior during this 
period, or attempt to evaluate Keynes's assertion regarding the dollar during late I933. ${ }^{5}$

In this article, I use high-frequency data to analyze the behavior of the dollar in the I920s and I930s (I92I through I936). I am particularly interested in establishing whether volatility was higher in the last months of 1933 - the time of operation of the gold-buying program criticized by Keynes - than during the rest of the period. The analysis is based on the estimation of Markov-switching regressions with regime-dependent variances to identify periods with different exchange rate volatility for the dollar-pound and dollar-franc exchange rates. The results obtained indicate that, for both exchange rates, it is possible to identify three volatility regimes. As Keynes suggested, when the gold-buying program was launched the dollar-pound exchange rate moved to the 'high-volatility' regime. However, towards the end of the program, the probability of being in the high-volatility regime declined significantly, and the exchange rate moved to the 'intermediate' volatility regime. Estimates for the dollar-franc also show that in early December I933 volatility switched from high to intermediate. At the time Keynes's letter was published, dollar-excessive gyrations had already begun to subside.

During the years under study $(\mathrm{I} 92 \mathrm{I}-36)$ there were vast changes in the international monetary system: the UK and France returned to the gold standard (in 1925 and 1926 respectively); the UK came off gold (I93 I); the US imposed a gold embargo and abandoned the gold standard (I933); the London World Conference failed to achieve stabilization (I933); the US devalued the dollar and adopted a new system with a fixed exchange rate relative to gold (I934); and France came off gold (I936). In Figure I I present weekly data for the dollar-British pound and dollar-French franc exchange rates for $\mathrm{I} 92 \mathrm{I}-36$. These data are measured as dollars per unit of foreign currency; higher values, then, represent dollar depreciation (see Appendix B for data sources).

The rest of the article is organized as follows: in Section II I discuss the path to dollar devaluation in I933, a process that began on 6 March, when President Roosevelt declared a national banking holiday. The section includes a detailed analysis of the 'gold-buying' program questioned by Keynes in his open letter. In Section III I deal with the dollar-pound exchange rate. I display and analyze the basic data, and I use Markov switching regressions with regime-dependent variances to study whether the extent of volatility during the gold-buying program was higher than during other times within the I92 I-36 period. In Section IV I turn to the dollar-franc

5 The letter is not mentioned in either of the two memoirs written by FDR's adviser Raymond Moley (I939, I966). In his thorough volume on the discussions leading to the Bretton Woods conference Steil (20 I3) deals with many of the interactions between Keynes and the Roosevelt administration - including his many memos to Secretary Henry Morgenthau during World War II - but he does not discuss in detail the NYT letter from December I933. In his monumental oeuvre on the gold standard, Eichengreen (1992) does not discuss Keynes's open letter. The letter is not mentioned in Friedman and Schwartz (1963), Temin (1976) or Meltzer (2003). 


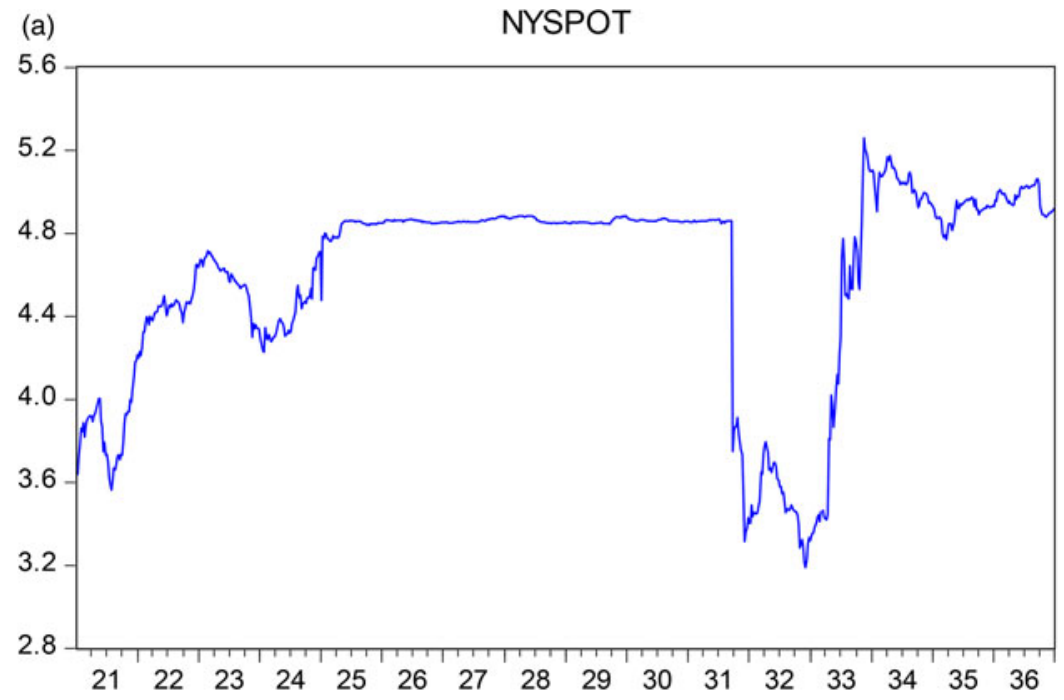

(b)

\section{FRANCSPOT}

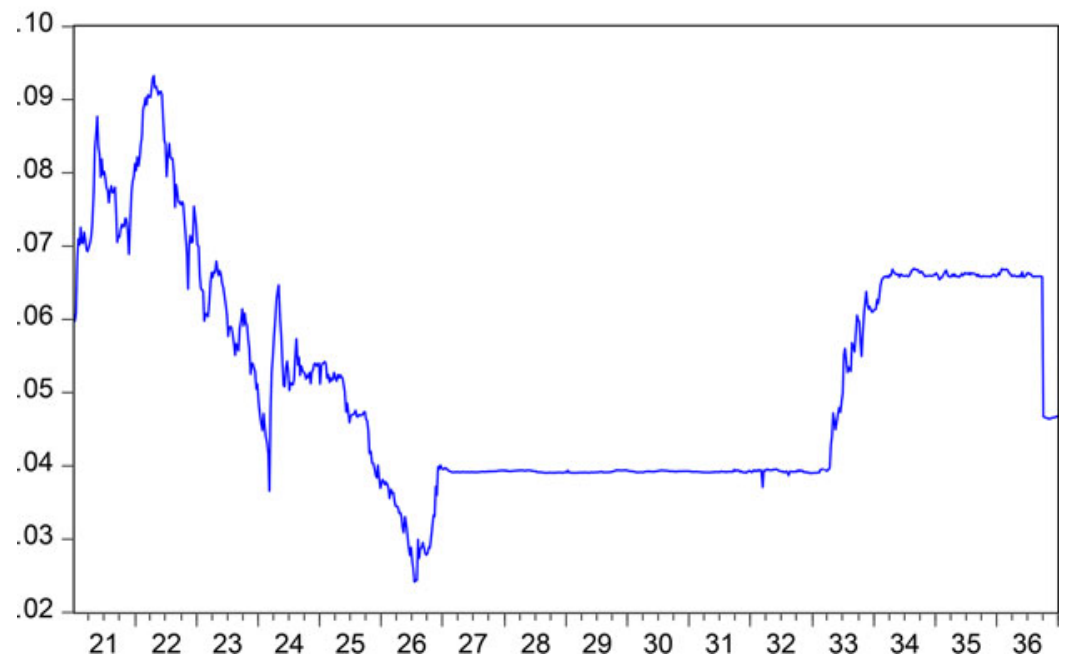

Figure I. Pound-dollar exchange rate, spot 1921-36 (weekly data)

Note: Numbers 2 I-36 in the horizontal axis refer to years I92 I through 1936.

and present the Markov switching regressions for this bilateral exchange rate. Section $\mathrm{V}$ contains closing remarks. Here I discuss the adoption of the Gold Reserve Act of I934, and Keynes's reaction to the fixing of the price of gold at $\$ 35$ an ounce. There are also two appendixes. In Appendix A, I put Keynes's advice in the open letter in perspective, by (briefly) analyzing his evolving policy views on exchange rates and gold. I point out that Keynes's plan for the international monetary system 
was similar to a plan developed by James P. Warburg, a close adviser of President Roosevelt. In Appendix B I present the data sources.

II. 1 From the gold embargo to the London Monetary and Economic Conference

In the early hours of 6 March I933, when he had been in office barely one day, President Roosevelt declared a national banking holiday, and implemented a gold embargo. The purpose of this policy was to stop massive withdrawals of currency and gold, and to put in place an emergency plan to strengthen the nation's financial system. ${ }^{6}$ The Secretary of the Treasury, Will Woodin, justified the embargo by saying that 'gold in private hoards serves no useful purpose under current circumstances. When added to the stock of the Federal Reserve Banks it serves as a basis for currency and credit. This further strengthening of the banking structure adds to its power of service toward recovery.'7 On 9 March Congress passed the Emergency Banking Act, which gave authority to the government to liquidate insolvent banks and to provide support to those that were viable in the long run. On I3 March, banks began to reopen their doors, and the public started to re-deposit their cash and gold in massive amounts. ${ }^{8}$ Although (most) banks opened gradually, the gold embargo remained in place. Three weeks later, on 5 April, President Roosevelt issued an Executive Order requiring people and businesses to sell, within three weeks, all their gold holdings to the government at the official price of $\$ 20.67$ per ounce. ${ }^{9}$

On I9 April, during the thirteenth press conference of his young presidency, President Roosevelt stated unequivocally that the country was now off the gold standard. Gold exports were prohibited. He declared that the fundamental goal of abandoning the monetary system that had prevailed since Independence was to help the agricultural sector, which had been struggling for over a decade. He stated: 'The whole problem before us is to raise commodity prices.' 10

The next step in the path towards devaluation came on I2 May, when Congress passed the Agricultural Adjustment Act (AAA). Title III of this legislation included the 'Thomas Amendment', which authorized the President to increase the official

${ }^{6}$ From a legal point of view, the declaration of a national banking holiday was based on the authority given to the President by the Trading with the Enemy Act of I9I 7. This was controversial, since at the time the United States was not at war.

7 'President invokes law on hoarders', NYT, 6 April I933, p. I.

8 FDR's First Fireside Chat, delivered over the radio on Sunday I2 March, helped generate confidence in the government actions towards banks. See Friedman and Schwartz (I963) for a detailed account of this episode.

9 Executive Order no. 6IO2. See Roosevelt (I938, vol. 2, pp. I I I-I4).

10 Roosevelt (I938, vol. 2, pp. I37-43). 
price of gold to up to $\$ 4$ I.34 an ounce. ${ }^{11}$ A devaluation of the dollar, many thought, would rapidly result in 'controlled inflation' and would help farmers by raising commodity prices and by lightening their debts when expressed in relation to their incomes. A number of analysts noted that Great Britain had devalued the pound in September I93 I, and had slowly begun to recover. They also pointed out that after devaluing sterling the UK had established a currency stabilization fund - the Exchange Equalization Fund.

However, there was a major difficulty in devaluing the dollar officially: most debt contracts - both private and public - included a 'gold clause', stating that the debtor committed himself to paying back in 'gold coin'. If the currency was devalued with respect to gold, the dollar value of debts subject to the gold clauses would automatically increase by the amount of the devaluation. This would result in massive bankruptcies and in a huge increase in the public debt. On 5 June, Congress passed Joint Resolution No. Io, annulling all gold clauses from future and past contracts. This opened the door for a possible official devaluation. ${ }^{12}$

One week after debt contracts were changed by Congress, on I 2 June, the London Monetary and Economic Conference was inaugurated by the King. The conference was supposed to last for twelve weeks and to deal with an array of issues, including international trade, credit policies, employment, protectionism, commodity prices, and the possible return of all nations to an 'international standard'. ${ }^{13}$ A key question addressed by representatives of the three largest economies - the US, Great Britain and France - was whether exchange rates should be stabilized during the duration of the conference. France's position was that without stabilization it was impossible to make progress on the other issues. The US and the UK were not opposed, in principle, to (temporary) stabilization. The question was at what rates to do it. This issue was negotiated in tripartite meetings that operated parallel to the official conference. ${ }^{14}$

On 3 July, the conference delegates were shocked by a message sent by President Roosevelt. He wrote that he was dismayed by the direction the discussions had taken. There was too much emphasis on short-run exchange rate stabilization and not enough on commodity prices and recovery. He added that the US would not participate in any effort to stabilize the exchanges in the immediate run, and that the conference's fixation with short-term stability responded to 'old fetishes of so-called international bankers'. ${ }^{15}$ He declared that the aim of the parley ought to be generating

11 The Thomas Amendment gave the President three options to help increase commodity prices: devaluing the dollar, remonetizing silver at a ratio of I6 to I relative to gold, or issuing up to 3 billion dollars of non-backed currency or greenbacks.

12 On I 8 February I935, the Supreme Court ruled for the government in what were known as 'the gold clause cases'.

13 See Paslovsky (I933).

14 For a detailed analysis of the London Conference, see Edwards (2017b).

15 Roosevelt (I938, vol. 2. pp. 264-5). 
mechanisms for 'controlled inflation'. ${ }^{16}$ Following Roosevelt's message - known as the 'bombshell' - the conference stalled, and three weeks later it adjourned without achieving any of its goals, not even the most modest ones.

The London Monetary and Economic Conference of I933 marks a major turning point in President Franklin D. Roosevelt's policies towards gold and exchange rates; there is a 'before London' and an 'after London'. After the conference, US policy towards the dollar became proactive and experimental; between October I933 and January I934 it was based on a program aimed at manipulating the world price of gold.

\section{II.2 The gold-buying program of October 1933}

As noted, during his first year in office, President Roosevelt repeatedly stated that one of the most important goals of his administration was to raise commodity prices. For example, on I9 April I933, after announcing that the US was abandoning the gold standard, he said: ${ }^{17}$

The whole problem before us is to raise commodity prices. For the last year, the dollar has been shooting up [this was a reference to the depreciating pound sterling] and we decided to quit competition. The general effect probably will be an increase in commodity prices. It might well be called the next step in the general program.

During the first half of August 1933 the President met several times with George F. Warren, a professor of agricultural economics at Cornell University, to discuss commodity markets. In I93 I Warren and his colleague Frank I. Pearson had published a book, Prices, where they analyzed price behavior for a score of products and countries during more than one hundred years. ${ }^{18}$ Their conclusion was that individual commodity prices went up and down because the world's stock of monetary gold increased and decreased through time. According to their results, the correlation between these variables was extremely high, almost perfect. This meant, they argued, that the easiest way to raise commodity prices was by increasing the dollar price of gold. Warren and Pearson emphasized that their approach had nothing to do with traditional monetary theory. For them, what the Federal Reserve did was rather irrelevant, as were the quantity theory of money and the equation of exchange. ${ }^{19}$

16 On 4 July, immediately after Roosevelt's communiqué, Keynes published an article in the Daily Mail where he congratulated the President for refusing to stabilize the exchanges in the short run. The article was titled 'President Roosevelt is magnificently right'. Keynes wrote that 'international exchange management should be an essential part of the policy which he has in view' (Keynes I982, p. 275).

17 Roosevelt (I938, p. I37). See Hausman et al. (2016) for a discussion on the farm channel in the US recovery from the Great Depression.

18 Warren and Pearson (I935). For an in-depth analysis of the work of George F. Warren and the goldbuying program, see of Sumner (2015, ch. 7). For a discussion of Warren's ideas in the context of the policy views of the early I930s, see Edwards (2017a).

19 In that sense, in spite of some superficial similarities, the Warren view differed significantly from Irving Fisher's 'compensated dollar' proposal. Warren and Pearson (I935, p. 94); Fisher (I9I3). 
In mid August, President Roosevelt decided to put Warren's theories to work, and asked Dean Acheson, the acting Secretary of the Treasury, to 'try his hand at a draft (for discussion only) of an Executive Order offering to buy newly minted gold for 30 days at a fixed price say $\$ 28$ an ounce and an offer to sell gold to the artists and dentists at the same price'. ${ }^{20}$ At the time the official price of gold was $\$ 20.67$. Two weeks later, on 29 August, Executive Order No. 626I was issued. The Secretary of the Treasury would now accept newly minted gold for sale on consignment. This metal could be sold to individuals authorized to acquire the metal - artists and dentists. The purchase price would be "equal to the best price obtainable in the free market of the world after taking into consideration any incidental expenses such as shipping costs and insurance'. ${ }^{21}$ The expectation was that by buying gold at the ongoing world price which was higher than the 'official' price of $\$ 20.87$ an ounce - agricultural prices would increase rapidly. Throughout September, however, commodity markets continued to be depressed. By the end of the month the price of corn was 28 percent lower than on Is July; the prices of cotton, rye and wheat had declined by I3, 30 and $2 \mathrm{I}$ percent relative to that date.

On Sunday 22 October, FDR delivered his Fourth Fireside Chat. He reiterated that the definitive goal of the government was to 'restore commodity price levels'. ${ }^{22} \mathrm{He}$ said that in order to accomplish this goal he had decided to expand the goldbuying program. The Reconstruction Finance Corporation (RFC) would buy newly minted gold at prices determined from time to time by the Secretary of the Treasury and the President. If needed, the RFC would also buy and sell gold in the world market at these prices. The most important difference between this new gold-buying program and the one established on 29 August was that under the original plan gold purchases were at ongoing world prices, while the new initiative permitted the government to set any price it wanted, and to alter it as frequently as it desired. ${ }^{23}$

On 25 October, the first day of the program, the RFC paid $\$ 3$ I.36 per ounce of gold, 27 cents above the world price. During the next 45 days or so, FDR, with Professor George F. Warren's assistance, determined every morning the price at which the RFC would buy gold during that day; almost always at a premium over the world price.

The RFC made its first international purchase on I November, when it bought a small batch of gold in France at $\$ 32.36$ an ounce. ${ }^{24}$ On 9 November, Jesse Jones, the chairman of the RFC, informed the press that since the launching of the program the

20 Acheson (1965, pp. I77-8).

21 Executive Order no. 626I may be found in Acheson (I965, pp. 258-9). Interestingly, it is not in FDR's Public Papers compilation.

22 Roosevelt (I938, vol. 2, p. 426).

23 In order to get around the fact that the official price of gold was still \$20.67 an ounce, the RFC paid with its own discounted debentures, which were immediately bought by the Treasury at par. See Acheson (1965).

24 'First gold buying puzzling to Paris', NYT, 3 November I933, p. 8. 
corporation had bought 2 I 3,000 ounces of newly minted gold domestically. He stated that the amount of gold bought in global markets was modest, but refused to divulge the exact amount. That day the price offered was \$33.I5 per ounce, Io cents higher than the international market price. On is November, an informed source who did not want to be identified stated that to that date purchases abroad had amounted to only \$6 million. By late December the RFC was paying \$32.6 I per ounce of gold. ${ }^{25}$

In early January I934, almost coincidentally with the publication of Keynes's open letter, the gold-buying program was effectively ended. ${ }^{26}$ On 3 I January I934, one day after the Gold Reserve Act of I934 was signed into law, the President set the new official price of gold at $\$ 35$ an ounce. The Treasury would buy and sell internationally any amount of metal at that price, in order to settle trade payments. Americans, however, were still forbidden from holding gold. This price was in place until mid I97I. See Section $v$ for a further discussion on the Gold Reserve Act.

\section{III}

Before proceeding to the empirical results, it is important to discuss which exchange rate Keynes had in mind when he penned his open letter. Was he alluding to the bilateral rate between the dollar and sterling? Was he thinking of the dollar-gold rate? Or was he focusing on a weighted average rate that included various currencies? ${ }^{27}$ According to Skidelsky (I992, p. 493), in the second half of I933 Keynes was mostly concerned with the volatility of the dollar-pound rate. More specifically, he thought that a US short-term policy goal should be 'to keep the dollar-sterling exchange rate as stable as was consistent with an accelerating programme of loan-financed public expenditure'. ${ }^{28}$ Skidelsky's views are supported by Keynes's own writings. Earlier that year, on 4 July, he published an article in the Daily Mail where he discussed FDR's 'bombshell' communiqué to the London Conference. In this piece Keynes supported FDR's decision to oppose short-term stabilization of the dollar, relative to gold, at a level that was inconsistent with higher commodity prices. But he added an important caveat. The President, he wrote, 'would be unwise...to reject every plan, however elastic it is, for regulating the dollar-sterling exchange'. ${ }^{29}$

This emphasis on the stability of the bilateral dollar-pound exchange rate was a short-term consideration. For the longer run, Keynes believed that all nations should try to stabilize their currency values relative to gold. He presented a specific plan for a new international financial system in the pamphlet The Means to

25 'Fluctuations surprise the capital', NYT, io November I933, p. 2.

26 Formally, the program continued through January I934, but there was only one price change: on I6 January, from $\$ 34.06$ to $\$ 34.45$ per ounce. As I point out below, if I extend the period considered under the program, the results are virtually identical.

27 Since in I933 (and until mid I936) the franc was fixed to gold, the volatility of the dollar rate was equal to that of the dollar-gold rate.

28 Skidelsky (I992, p. 493), emphasis added.

29 Keynes (I982, p. 275), emphasis added. 


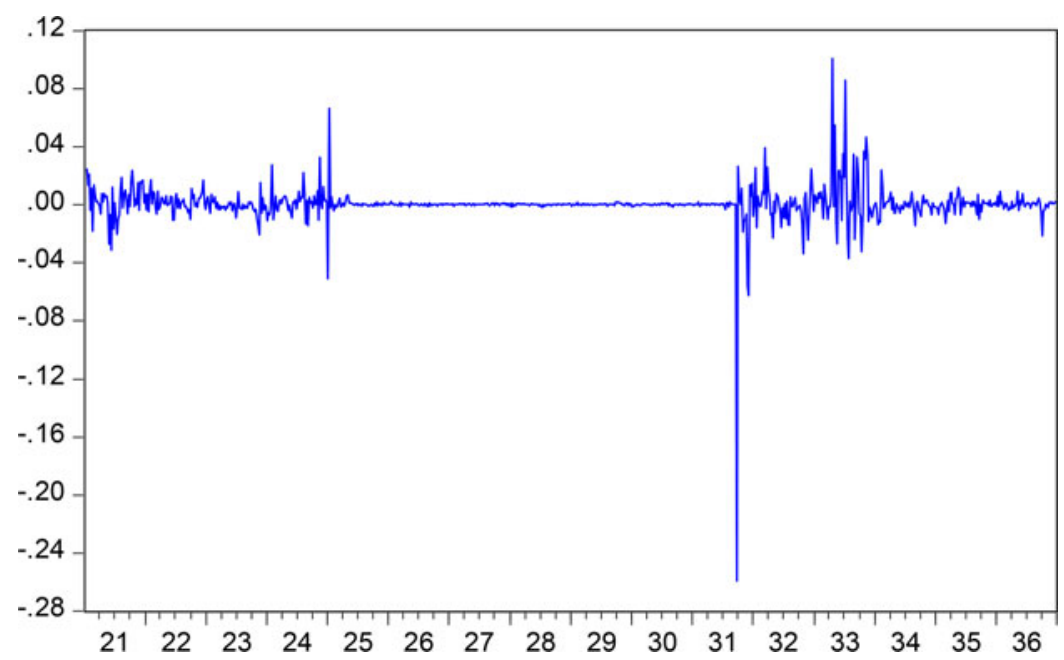

Figure 2. Weekly percentage change pound-dollar rate

Note: Numbers 2 I-36 in the horizontal axis refer to years I92 I through 1936.

Prosperity, published in March of I933. He referred to this plan as a 'qualified return to the gold standard'. Under it, he asserted, 'stability of the foreign exchanges... would ensue'. ${ }^{30}$ In Appendix A of this article I discuss Keynes's proposal, and I compare it with a plan independently developed in mid I933 by FDR's adviser James P. Warburg.

\section{1 Preliminary analysis for the dollar-pound}

In the rest of this section I analyze the extent of volatility of the dollar-pound exchange rate during $\mathrm{I} 92 \mathrm{I}-36$. As noted, the main purpose of this analysis is to assess whether, as Keynes argued in his open letter, during the gold-buying program of I933 the dollar became excessively volatile. In Section IV, I expand the analysis to the dollar-franc bilateral exchange rate.

Figure 2 presents the weekly percentage change of the pound-dollar exchange rate. Visual inspection suggests four chronological phases. ${ }^{31}$ (I) A volatile period before the return of the UK to gold. This phase goes from January I92 I to April I925. (2) A (very) tranquil period corresponding to the time when both the US and the UK were on the gold standard, from May i925 to September I93 I. During this phase exchange rate changes were minimal and stayed within the 'gold points'. (3) A turbulent period following the abandonment of gold by the UK in September I93 I. This

30 See Keynes (I933a, ch. IV).

31 A 'chronological phase' is not the same as a 'volatility regime'. The former refers to changes in the extent of volatility through time, while the latter focuses on the structural characteristics of different regimes. It is possible that there are many different chronological changes, characterized by moves in and out of a smaller number of 'regimes'. 
Table I. Dollar-pound exchange rate, 1921-36 (weekly percentage changes $\left.{ }^{a}\right)$

\begin{tabular}{|c|c|c|c|c|c|}
\hline & Mean & Median & Maximum & Minimum & $\begin{array}{l}\text { Standard } \\
\text { deviation }\end{array}$ \\
\hline $\begin{array}{l}8 \text { Jan I92 I - } \\
25 \text { Apr I925 }\end{array}$ & 0.00127 & 0.00046 & 0.06630 & -0.05II5 & 0.00995 \\
\hline $\begin{array}{l}5 \text { May I925- } \\
\text { I5 Sept I93 I }\end{array}$ & 0.00000 & 0.00000 & 0.00206 & -0.00355 & 0.00062 \\
\hline $\begin{array}{l}\text { 21 Sept I93 I - } \\
\text { 2I Oct I933 }\end{array}$ & -0.00033 & -0.00028 & $0.1007 \mathrm{I}$ & -0.25928 & 0.03315 \\
\hline $\begin{array}{l}\text { I9 Apr I933- } \\
4 \text { Jul I933 }\end{array}$ & O.OI9I & O.OI79I & 0.10070 & -0.0268 & $0.034 \mathrm{I} 2$ \\
\hline $\begin{array}{l}\text { Gold-buying program } \\
(23 \text { Oct - 3 I Dec I933) }\end{array}$ & 0.01004 & -0.001923 & 0.04633 & -O.OI I 47 & 0.02216 \\
\hline Complete period & 0.00036 & 0.00000 & 0.10070 & -0.25928 & O.OI 339 \\
\hline
\end{tabular}

${ }^{\mathrm{a}} \mathrm{A}$ positive number denotes a depreciation of the dollar; a negative number is an appreciation of the dollar and a depreciation of the pound.

volatile period continued after the abandonment of gold by the US in April I933, and lasted until late January I934. Notice that the 'gold-buying' program takes place towards the end of this phase, and is highlighted by a shaded area in Figure 3 (25 October - 3 I December I933). And (4), a period of limited variability which took place after the Gold Act was passed by the US Congress on 30 January I934.

As a preliminary step, in Table I I present descriptive statistics for five subperiods, and for the complete period, I92 I-36. In addition to the four chronological phases mentioned above, I have included the period that extends from the announcement that the US was off gold (I9 April I933) to the effective end of the London Conference, with FDR's 'bombshell' (4 July I933). As may be seen, there are significant differences across subperiods. For instance, the standard deviation corresponding to the gold-buying period is among the highest of all subperiods. In Table 2 I report on a battery of tests for the equality of variances between the gold-buying program (25 October - 3I December I933) and I92I-5 and I93I-3. The results in Panel A indicate that the null hypothesis of equality of variances is rejected under all tests for the comparison of the gold-buying program and first turbulent period (I92I-5). On the other hand, as may be seen in Panel B, the null of equality of variance during the gold-buying program and the post-UK gold period (September I93 I - October I933) cannot be rejected in three of the four tests. ${ }^{32}$

32 Notice that in this comparison the devaluation of the pound on 2I September I93 I - which resulted in a negative spike equal to -0.27 - is part of the post-gold sample. If this specific observation is removed from the sample, and the analysis is started on 28 September, the standard deviation for the post-gold period becomes $0.02 \mathrm{I} 7 \mathrm{O}$, slightly lower than that of the gold-buying program. In 
Table 2. Test of equality of variances: dollar-pound

A. Between the period 8 January 1921 - 25 May 1925 and gold-buying program (23 October - 31

December 1933)

\begin{tabular}{lccc}
\hline \hline Method & df & Value & Probability \\
\hline F-test & $(224, \mathrm{IO})$ & 4.960527 & 0.0080 \\
Siegel-Tukey & & 2.822474 & 0.0048 \\
Bartlett & $\mathrm{I}$ & $\mathrm{I} 9.90946$ & 0.0000 \\
Levene & $(\mathrm{I}, 234)$ & $32.6 \mathrm{I} 339$ & 0.0000 \\
Brown-Forsythe & $(\mathrm{I}, 234)$ & $\mathrm{I} 6.44937$ & O.OOO I \\
\hline \hline
\end{tabular}

B. Between the period 21 September 1931- 20 October 1933 and gold-buying program (23 October-31 December 1933)

\begin{tabular}{lccc}
\hline \hline Method & df & Value & Probability \\
\hline F-test & (IO, IO7) & $2.23943 \mathrm{I}$ & $0.04 \mathrm{I} 2$ \\
Siegel-Tukey & & 0.564250 & 0.5726 \\
Bartlett & I & 2.3 I $468 \mathrm{I}$ & 0.1282 \\
Levene & (I, I I $)$ & 0.174920 & 0.6765 \\
Brown-Forsythe & (I, I I7) & 0.005899 & 0.9389 \\
\hline \hline
\end{tabular}

III. 2 Markov switching regressions: weekly data, 1921-36

In this subsection I present the results from the estimation of Markov switching regressions with regime-dependent variances to identify periods with different degrees of exchange rate volatility. As noted, I use weekly data for I92 I-36. An advantage of this methodology is that the researcher does not incorporate his priors into the analysis; instead of arbitrary defining (and comparing) different volatility phases, the data are asked to determine how many distinct volatility regimes may be identified. The data are also asked at which dates the degree of volatility switched across regimes. The basic Markov-switching model with regime dependent variances has the following form: ${ }^{33}$

$$
d \log x_{t}=\gamma(k)+\sigma(k) \varepsilon_{t}
$$

Where $d \log x_{t}$ is the weekly percentage change of the pound-dollar rate, $\gamma(k)$ is a linear regression function that may depend on the $k$ regimes, $\boldsymbol{\varepsilon}_{t}$ is an iid normally distributed error term, with a standard deviation that is also regime dependent and may

this case it is not possible to reject, with any of the four tests, the null hypothesis of equality of variance across these two periods. When other subperiods are compared to the gold-buying program, the results are similar.

33 See Hamilton (1989), Hamilton and Susmel (I994). 
exhibit some form of autocorrelation. This type of switching volatility model was developed by Hamilton and Susmel (1994), and has been used by Edwards and Susmel (200I), among others, to analyze exchange rate volatility around turbulent periods. In Markov models the regime probabilities $p(k)$ are assumed to depend on the previous state (Hamilton I989):

$$
P\left(s_{t}=i \mid s_{t-1}=j\right)=p_{j i}(t)=p_{j i}(t) .
$$

The intercept in $\gamma(k)$ in equation (I) is regime dependent and may be interpreted as (partially) capturing the degree of risk aversion in each regime. We anticipate that in the case at hand there will be, at least, two regimes: one corresponding to very low volatility, which would include the years when both countries were under the gold standard, and a different, high volatility state, when one of the two nations (or both of them) was off gold. The key question is whether it is possible to identify more than one turbulent regime. If this is the case, we are interested in understanding which of these volatile regimes the gold-buying program belongs to. More specifically, the question is whether the gold-buying period corresponds, as Keynes suggests in his letter, to the regime with the highest volatility or whether, on the contrary, it falls in the regime with intermediate volatility.

\section{Base case results}

In the base case estimates I allow for a regime-dependent intercept, a lagged dependent variable and regime-dependent variance. The error is assumed to have a common AR(I) term. Hansen likelihood tests indicate that the best characterization of the period under study corresponds to three regimes. ${ }^{34}$ The results for the Markov regressions are given in Table 3: Regime I corresponds to intermediate volatility; Regime 2 to low volatility; and Regime 3 to high volatility. All estimates of the regime-dependent variance, $\log$ (sigma), are significant at conventional levels, as are the coefficients for the lagged dependent variables, and the common AR(I) term. When slightly different specifications were used, three regimes were still identified and the relative values of the coefficients were maintained (more on this below). As may be seen in Table 3, the differences in the extent of volatility across the three regimes are significant: the estimated variance during the high-volatility regime is 7.3 times higher than the estimated variance for the intermediate volatility regime. The latter is, in turn, 8.4 times higher than the estimated variance during the tranquil period.

Table 4 provides a summary of the transitional probabilities and the regimes' duration. As may be seen, the diagonal probabilities are very high, indicating that there is significant regime persistence. This table also shows that there is a 17.5 percent probability that if the system is in the high-volatility regime, the following week it will be in the intermediate-volatility one. The probabilities of moving from some degree of volatility (either intermediate or high) to tranquility, or vice versa, are very low. As

\footnotetext{
34 Hansen (I992, I996). See Edwards and Susmel (200I) for a discussion of this test.
} 
Table 3. Markov switching regression, dollar-pound: 1921-36, regime-dependent variances

Sample (adjusted): 29 January I92 I - 22 August I936

Included observations: $8 \mathrm{I} 3$ after adjustments

Number of states: 3

\begin{tabular}{lrrrr}
\hline Variable & Coefficient & Std error & \multicolumn{1}{c}{ z-statistic } & Prob. \\
\hline Regime I & & & & \\
\hline C & $5.40 E-05$ & $5.72 \mathrm{E}-05$ & 0.944858 & 0.3447 \\
INTER_POUND(-I) & -0.242835 & 0.069892 & -3.474439 & 0.0005 \\
LOG(SIGMA) & -5.320473 & 0.105962 & $-50.21 \mathrm{I} 33$ & 0.0000 \\
\hline
\end{tabular}

Regime 2

\begin{tabular}{lrlrl}
\hline C & I.94E-05 & $2.46 \mathrm{E}-05$ & 0.785776 & 0.4320 \\
INTER_POUND(-I $)$ & -0.343724 & $0.073 \mathrm{IO}$ & -4.701950 & 0.0000 \\
LOG(SIGMA) & -7.459224 & $0.05 \mathrm{I} 695$ & $-\mathrm{I} 44.2939$ & 0.0000 \\
\hline
\end{tabular}

Regime 3

\begin{tabular}{lcccc}
\hline C & -0.001158 & 0.002224 & -0.520850 & 0.6025 \\
INTER_POUND(-I) & -0.282052 & 0.121289 & -2.325460 & 0.0200 \\
LOG(SIGMA) & -3.338908 & 0.313940 & -10.63550 & 0.0000 \\
\hline
\end{tabular}

Common

\begin{tabular}{|c|c|c|c|c|}
\hline $\operatorname{AR}(\mathrm{I})$ & 0.332117 & 0.064297 & 5.165352 & 0.0000 \\
\hline \multicolumn{5}{|c|}{ Transition Matrix Parameters } \\
\hline PII-C & 2.938974 & 0.325846 & 9.019517 & 0.0000 \\
\hline PI2-C & -2.291792 & I.057459 & -2.167263 & 0.0302 \\
\hline $\mathrm{P}_{2 \mathrm{I}}-\mathrm{C}$ & -0.001054 & I.96E-05 & -53.62954 & 0.0000 \\
\hline $\mathrm{P}_{22-\mathrm{C}}$ & 5.620594 & 0.656243 & $8.5648 \mathrm{I} 2$ & 0.0000 \\
\hline $\mathrm{P}_{3} \mathrm{I}-\mathrm{C}$ & $-\mathrm{I} .553699$ & 0.416306 & $-3.732 \mathrm{IO} 8$ & 0.0002 \\
\hline $\mathrm{P}_{32-\mathrm{C}}$ & -20.08926 & 0.056927 & -352.8968 & 0.0000 \\
\hline Mean dependent var & 0.000354 & \multicolumn{2}{|c|}{ S.D. dependent var } & O.0I3479 \\
\hline S.E. of regression & 0.013565 & \multicolumn{2}{|c|}{ Sum squared resid } & O.I 47756 \\
\hline Durbin-Watson stat & $2.04930 \mathrm{I}$ & \multicolumn{2}{|c|}{ Log likelihood } & 3552.688 \\
\hline Akaike info criterion & -8.700338 & \multicolumn{2}{|c|}{ Schwarz criterion } & -8.607827 \\
\hline Hannan-Quinn criter. & -8.664827 & & & \\
\hline Inverted AR Roots & .33 & & & \\
\hline
\end{tabular}

anticipated, the low-volatility regime has the longest expected duration, at I 39 weeks. The expected duration of high-volatility regimes is I 8.2 weeks, and that of intermediate volatility is only 5.7 weeks. 
Table 4. Markov transition summary, dollar-pound: transition probabilities and regime duration

Transition summary: Constant Markov transition probabilities and expected durations Sample (adjusted): 29 January I92 I - 22 August I936

Included observations: 8 I 3 after adjustments

Constant transition probabilities:

$\mathrm{P}(\mathrm{i}, \mathrm{k})=\mathrm{P}(\mathrm{s}(\mathrm{t})=\mathrm{k} \mid \mathrm{s}(\mathrm{t}-\mathrm{I})=\mathrm{i})$

(row $=\mathrm{i} /$ column $=\mathrm{j}$ )

\begin{tabular}{lllc} 
& $\mathrm{I}$ & 2 & 3 \\
$\mathrm{I}$ & 0.944939 & 0.005055 & 0.050006 \\
2 & 0.003593 & $0.9928 \mathrm{II}$ & 0.003596 \\
3 & 0.174553 & $\mathrm{I} .56 \mathrm{E}-09$ & 0.825447 \\
& & & 3 \\
& $\mathrm{I}$ & 2 & $5.72893 \mathrm{I}$ \\
\hline
\end{tabular}

Figure 3 contains the smoothed regime probabilities corresponding to the base-case estimates. As expected, the low-volatility regime (Regime 2) is correctly identified as the period when both nations were on the gold standard and the dollar-pound exchange rate moved within the gold points. As expected, the post-Gold Reserve Act of 1934 period - when a new official price of gold in the US was set at \$35 an ounce - corresponds to intermediate volatility; during this period the pound was still off gold and fluctuated according to market forces (although the British intervened from time to time through their Exchange Equalization Fund, established on I9 April 1932). As may be seen, between September I93 I and January I934, there are several shifts from high to intermediate, and back to high volatility. In addition, and as is shown in greater detail below, the system moves into high volatility at the beginning of the gold-buying period, but half way through it, it switches back to intermediate volatility.

In order to analyze in greater detail regime switches during the latter part of I933, in Figure 4 I zoom in on the transitional probabilities for the intermediate and highvolatility regimes between I August and 3 I December I933. For expository reasons I have excluded the low-volatility probabilities; they are mostly zero during these 24 weeks. This figure shows that the system moved into the high-volatility regime during the last week of August, at the time the original gold-buying program, which purchased metal at ongoing world prices, was announced and launched (Executive Order no. 626I). The dollar-pound rate stayed on the high-volatility regime until the last week of November, when it switched to intermediate volatility. That is, Keynes was right in pointing out that the gold-buying program generated high-dollar 'gyrations', but what he failed to notice (or to mention) is that towards the end of the period this volatility had abated, and that the pound-dollar rate was back to an intermediate volatility regime. Keynes also failed to mention that although 

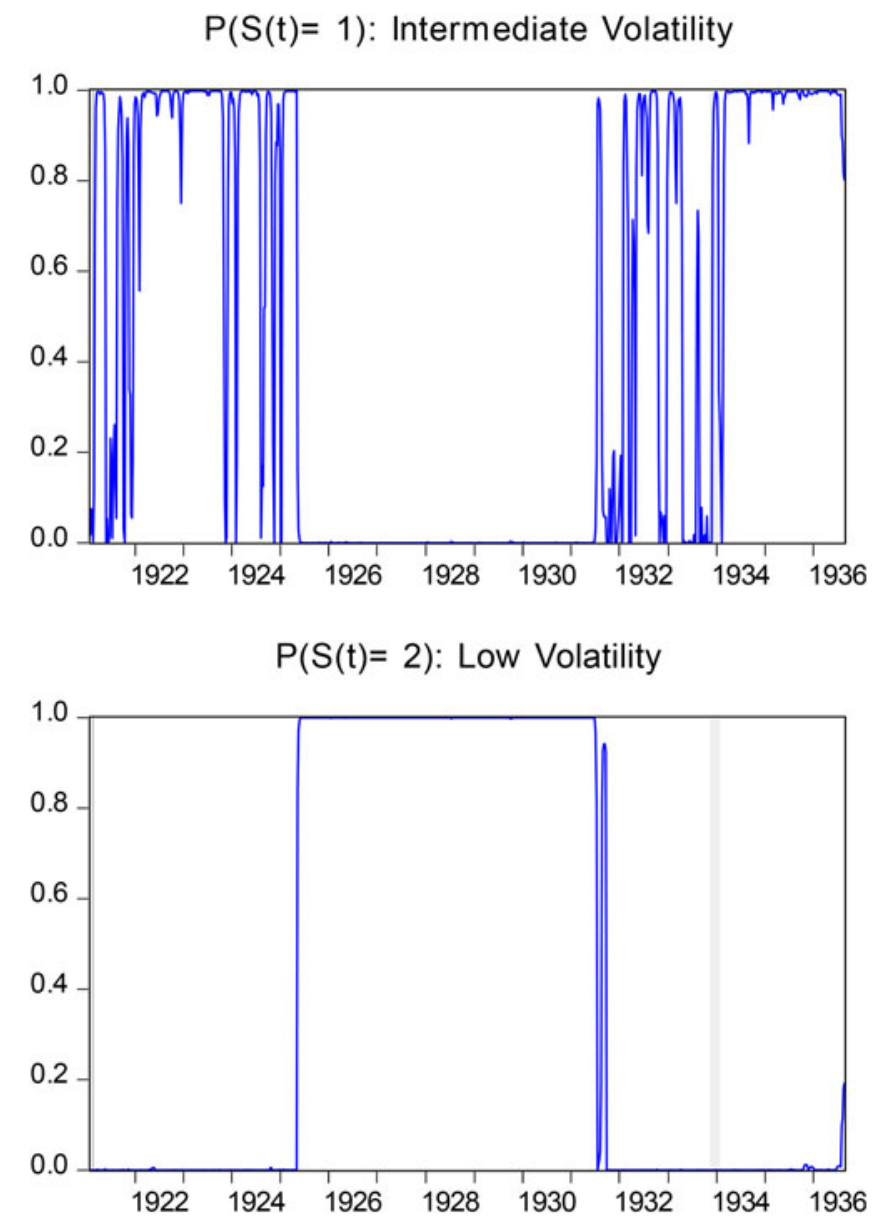

$P(S(t)=3)$ : High Volatility

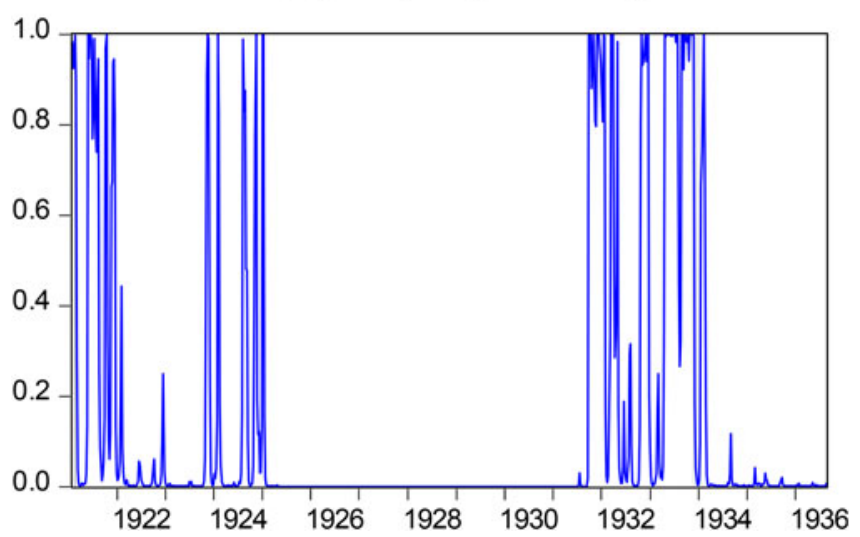

Figure 3. Regime-smoothed probabilities, dollar-pound: weekly data, 1921-36 


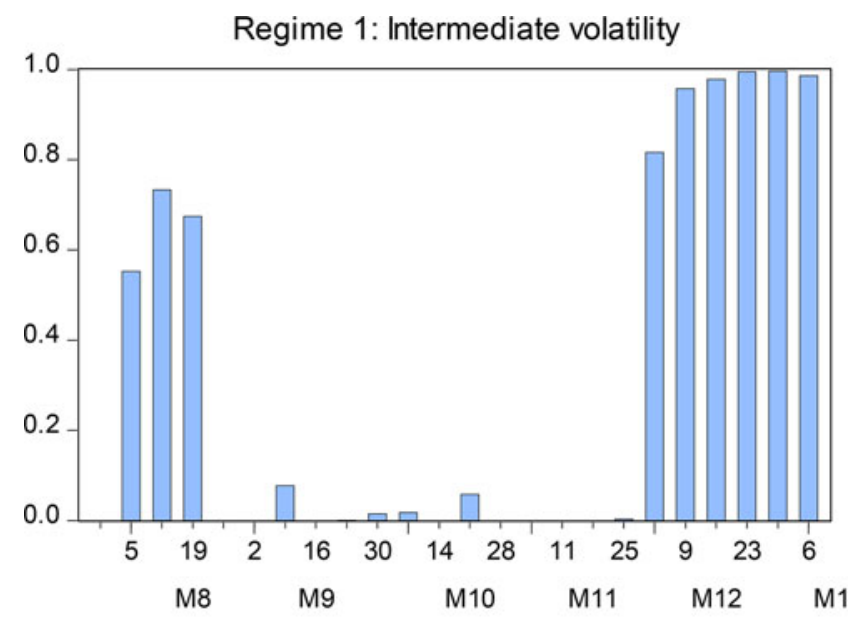

Regime 3: High volatility

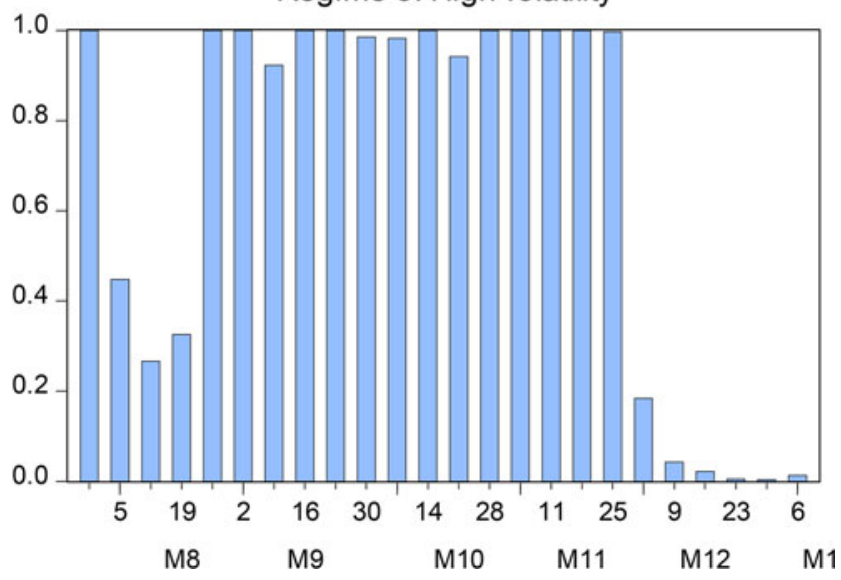

Figure 4. Regime-smoothed probabilities, dollar-pound: weekly data, August-December 1933 Note: M8, M9 and so on refer to August 1933, September 1933 and so on.

during the gold-buying program the dollar-sterling bilateral rate was characterized by high volatility, this was not higher than during other periods around that time. As may be seen in Figure 4, the dollar-sterling rate was also in a high-volatility regime for several weeks after the UK abandoned gold in September I93I, and for some weeks during I92 I and I924-5. ${ }^{35}$ According to this analysis, it is not possible to identify a different regime (with even higher volatility) during the gold-buying program.

35 Immediately after September I93 I heightened volatility was due to the fact that the UK came off gold. However, as shown in the section on the French franc, at that time the dollar-franc rate also experienced an increase in volatility. 
An interesting question is why volatility declined towards the end of November I933. The most plausible explanation is that the administration realized that the discretionary way in which the RFC prices were determined generated heightened uncertainty. It was around that time when Jacob Viner - the respected University of Chicago professor, who would become an adviser to the Treasury in $1934-$ wrote a longish memorandum to Henry Morgenthau, Jr (then the acting Secretary of the Treasury), where he explained that the gold-buying program was not working as promised. A serious problem, Viner asserted, was that the purchases abroad were too small, and did not really change the international price of gold. In addition, the discretionary changes in the price of gold, and the absence of a clear program geared towards stabilization, were encouraging speculation, and negatively affecting investment decisions. ${ }^{36}$ Starting in mid December, daily prices paid by the RFC changed more gradually, and the RFC premium became smaller and more stable. Data from the forward markets for the dollar relative to several currencies, collected by Einzig (I937), suggest that starting in the second week of December the market began to sense that a major change to the exchange rate regime was in the works. ${ }^{37}$

\section{Robustness and extensions}

In order to test for the robustness of the results reported above, I estimated a number of Markov-switching regressions with alternative specifications. In particular, I introduced additional regressors, including the one-month forward premium in the exchange rate market (see Appendix A for data sources). As may be seen from Table 5, the coefficient for this variable is significantly positive. More importantly, the results regarding the number of regimes, the relative sizes of the variance in each of them and the transitional probabilities are very similar to those reported in the base case estimates and discussed above, and provide support for the main conclusions of the analysis. Notice that in Table 5 the forward premium was introduced as a regressor that is not regime dependent. However, if it is included as depending on the regime, the results are very similar, and don't affect the conclusions in any significant way (results available on request).

I also analyzed whether there were switches in the volatility regime around important dates during I933-4. In addition to the gold-buying program I considered: (a) the passage of the Emergency Banking Act on 9 March I933; (b) the President's announcement that the country was off gold on I9 April; (c) the approval of the Thomas Amendment on I 2 May; (d) Congress's joint resolution of 5 June, abrogating the gold clauses; (e) the inauguration of the London Monetary and Economic Conference on I2 June; and (f), the passage of the Gold Reserve Act of I934. The results from the Markov switching regressions indicate that there were switches in the volatility regime around three of these events (see Figure 3): the abandonment

36 Blum (I959, p. I2 I); Jacob Viner Papers, box 49, folder I.

37 Einzig (I937) reports weekly data for the one- and three-month forward contracts for a number of currencies. 
Table 5. Markov switching regression, dollar-pound: 1921-36, regime-dependent variances, alternative specification

Sample (adjusted): 29 January I92 I - 22 August I936

Included observations: 8 I I after adjustments

Number of states: 3

Variable Coefficient Std error z-statistic Prob.

Regime I

\begin{tabular}{lrrrr}
\hline C & $0.000 \mathrm{I} 60$ & $0.0003 \mathrm{I} 6$ & 0.507207 & $0.6 \mathrm{I} 20$ \\
INTER_POUND(-I) & -0.259786 & 0.056558 & -4.593273 & 0.0000 \\
LOG(SIGMA) & -5.336555 & 0.058729 & $-90.8668 \mathrm{I}$ & 0.0000 \\
\hline
\end{tabular}

Regime 2

\begin{tabular}{lllrr}
\hline C & $-2.76 \mathrm{E}-05$ & $3.80 \mathrm{E}-05$ & -0.726664 & 0.4674 \\
INTER_POUND(-I) & -0.376494 & 0.058864 & -6.396056 & 0.0000 \\
LOG(SIGMA) & $-7.487 \mathrm{I} 27$ & $0.0409 \mathrm{II}$ & $-\mathrm{I} 83.0090$ & 0.0000 \\
\hline
\end{tabular}

Regime 3

\begin{tabular}{lcccc} 
C & $-0.0006 \mathrm{I} 9$ & 0.001257 & -0.492474 & 0.6224 \\
INTER_POUND(-I) & -0.289452 & 0.098957 & -2.925027 & 0.0034 \\
LOG(SIGMA) & $-3.342 \mathrm{I} 48$ & 0.076533 & -43.66944 & 0.0000 \\
\hline
\end{tabular}

Common

\begin{tabular}{lllll}
\hline NYFWDiM & 0.000859 & 0.000196 & 4.375655 & 0.0000 \\
AR(I) & $0.34 \mathrm{I} 201$ & 0.046958 & 7.266057 & 0.0000 \\
\hline
\end{tabular}

Transition Matrix Parameters

\begin{tabular}{|c|c|c|c|c|}
\hline PII-C & 5.592946 & 0.654975 & 8.539176 & 0.0000 \\
\hline PI2-C & -0.023410 & 0.095268 & -0.245725 & 0.8059 \\
\hline $\mathrm{P}_{2 \mathrm{I}}-\mathrm{C}$ & $-\mathrm{I} 7.64594$ & 7I.6I799 & -0.246390 & 0.8054 \\
\hline $\mathrm{P}_{22-\mathrm{C}}$ & I.536399 & 0.325615 & $4.7 \mathrm{I} 846 \mathrm{I}$ & 0.0000 \\
\hline $\mathrm{P}_{3} \mathrm{I}-\mathrm{C}$ & -5.182928 & 0.765087 & -6.774299 & 0.0000 \\
\hline $\mathrm{P}_{32-\mathrm{C}}$ & -2.875805 & 0.298437 & -9.636229 & 0.0000 \\
\hline Mean dependent var & $0.00035 \mathrm{I}$ & \multirow{5}{*}{\multicolumn{2}{|c|}{$\begin{array}{l}\text { S.D. dependent va1 } \\
\text { Sum squared resid } \\
\text { Log likelihood } \\
\text { Schwarz criterion }\end{array}$}} & O.OI 3494 \\
\hline S.E. of regression & 0.013676 & & & O.I 49624 \\
\hline Durbin-Watson stat & 2.045 II 2 & & & $3555 \cdot 3 \mathrm{I} 8$ \\
\hline Akaike info criterion & $-8.7258 \mathrm{I} 4$ & & & \\
\hline Hannan-Quinn criter. & -8.688006 & & & \\
\hline Inverted AR Roots & .34 & & & \\
\hline
\end{tabular}


of the gold standard (I9 April), the gold-buying program (October and December I933) and approval of the Gold Reserve Act of I934. ${ }^{38}$

I also invesigated whether some of the important political events during I92 I-36 were reflected in switches of volatility regime. In particular, I focused on changes in government in the three main powers of the time - the US, the UK and France. No significant mapping from these events to volatility switches was found before I933. I also inquired whether the ascendance of the Nazis in Germany was, in any way, reflected in volatility switches. The results suggest that shortly after Hitler became chancellor, the dollar-pound moved to high volatility. It is difficult, however, to fully ascribe that development to politics in Germany, since at almost exactly the same time the US was going through major financial upheaval, including the declaration of the national banking holiday in early March I933. ${ }^{39}$

\section{IV}

In this section I expand the analysis to the dollar-franc. In Figure 5 I present the weekly percentage change in this bilateral exchange rate. In Table 6, on the other hand, I present the Markov switching regression results. Figure 6 contains the smoothed transitional probabilities. ${ }^{40}$

In this case it is also possible to identify three volatility regimes. Regime I corresponds to low volatility, Regime 2 is for high volatility, and Regime 3 to intermediate volatility. As may be seen from Table 6 , the coefficient for the log of the variances is always significant, as is the common $\operatorname{AR}(\mathrm{I})$ term. When alternative specifications are used - for instance, when the forward premium is included - the results are very similar to those reported in Table 6. Expected durations for the three regimes are as follows: Regime I (low volatility), 30.3 weeks; Regime 2 (high volatility), 55.9 weeks; and Regime 3 (intermediate volatility), I 5. I weeks; notice that these durations are quite different from those for the dollar-pound reported in Table 4. For the dollar-franc bilateral exchange rate the three regimes exhibit a significant degree of persistence; the diagonal elements in the transition matrix are very high: 0.967 , 0.982 and 0.933 .

The smoothed transitional probabilities, presented in Figure 6, are particularly interesting: as may be seen, and as expected, the dollar-franc rate exhibits low volatility during most of the December I926 - September I93 I period. This phase begins

38 As will be seen below (Section IV), there was also a regime switch in the dollar-franc rate in late I93 I. In addition to the abandonment of the gold standard by the UK, this switch may have reflected other important events, including the debt moratorium instituted by President Hoover in June of that year, and the crisis of Austria's largest bank (the Credit Anstalt).

39 On 6 March, newspapers across America announced the national banking holiday and the gold embargo on the front page. Most papers also carried, on the front page, reports that Hitler and the Nazis had won a majority in Germany's elections.

40 Notice that, since the franc was fixed to gold between late December 1926 and September I936, during this period dollar-franc volatility is equal to dollar-gold volatility. 


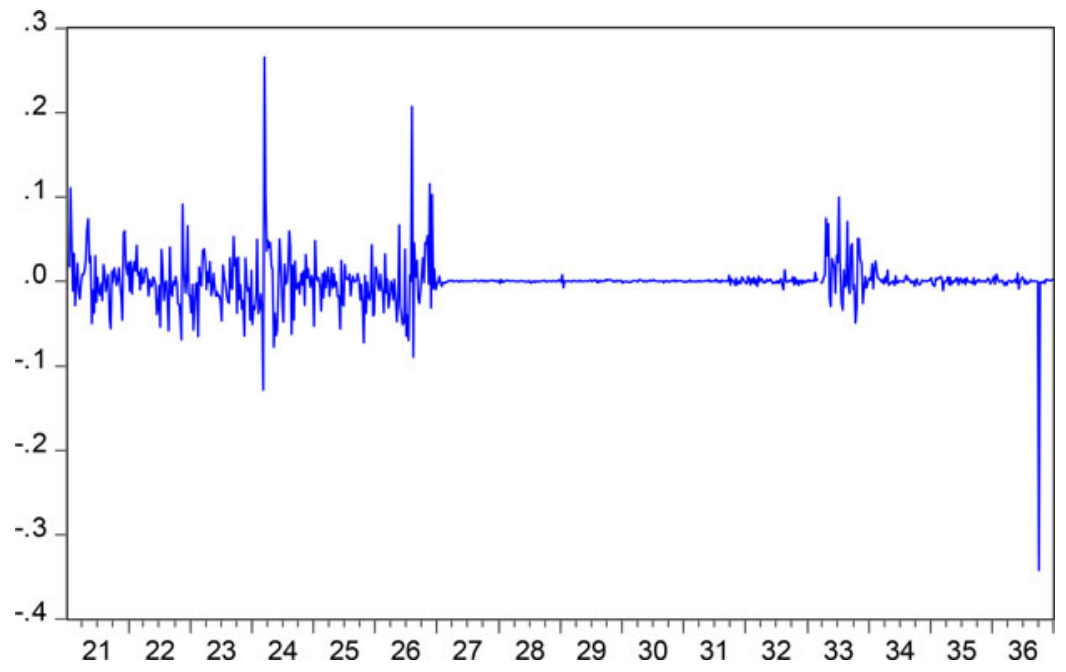

Figure 5. Weekly percentage change franc-dollar rate, 1921-36

Note: Numbers $2 \mathrm{I}-36$ in the horizontal axis refer to years I92 I through I936.

with France's return to the gold standard, and ends when the UK came off gold. Between late September I93 I and mid April I933 - when FDR took the US off gold - the dollar-franc rate is in the intermediate volatility regime. This is an interesting result, which suggests that once the UK abandoned the gold standard, the market became somewhat skittish about the dollar. Indeed, at the time some market participants believed that the US would follow the UK, and come off gold. ${ }^{41}$

On the week of 22 April I933 - immediately after FDR made the announcement that the US was officially off gold - there is significant jump in regime probabilities: the probability of being in the intermediate regime declined from $0.9 \mathrm{I} 2$ to almost zero, and the probability of being in the high-volatility regime jumped from 0.09I two weeks earlier to almost I.O.

The results in Figure 6 indicate that when the first phase of the gold-buying program was launched in late August I933, the dollar-franc rate was already in the high-volatility regime (the probability had been close to I.O since 22 April I933). The results also show that in mid December - in the midst of the gold-buying program - there was a significant decline in the probability of being in the high-volatility regime. According to these estimates, during the week of 2 December, the probability of being in the high-volatility regime was almost equal to I.o; a week later, on 9 December, that probability had declined to 0.48 ; and in the week of I6 December it had dropped further to 0.24 . By the end of the year (30 December) the probability of the dollar-franc exchange being in the high-volatility regime was a low 0.I 5 . During

${ }^{41}$ Remember that since in I93 I the franc was (firmly and credibly) fixed with respect to gold, volatility in the dollar-franc rate was equivalent to volatility in the dollar-gold rate. Eichengreen (I992) discusses in detail the dollar pressures during late I93 I and early 1932. See also Edwards (2017b). 
Table 6. Markov switching regression, dollar-franc: 1921-36, regime-dependent variances

Sample (adjusted): 29 January I92 I - 22 August I936

Included observations: $8 \mathrm{I} 3$ after adjustments

Number of states: 3

\begin{tabular}{lrrrr}
\hline Variable & Coefficient & Std error & \multicolumn{1}{c}{ z-statistic } & Prob. \\
\hline Regime I & & & & \\
\hline C & & & & \\
INTER_FRANC(-I) & I.49E-05 & $3.69 \mathrm{E}-05$ & 0.404900 & 0.6856 \\
LOG(SIGMA) & $-7.22495 \mathrm{I} 4$ & 0.075587 & 3.684673 & 0.0002 \\
\hline
\end{tabular}

Regime 2

\begin{tabular}{lrrrr} 
C & $-0.000 \mathrm{III}$ & $0.00 \mathrm{I} 6 \mathrm{I} 9$ & -0.068494 & 0.9454 \\
INTER_FRANC(-I) & $0.3394 \mathrm{I} 5$ & $0.058 \mathrm{I} 25$ & $5.8394 \mathrm{I} 8$ & 0.0000 \\
LOG(SIGMA) & -3.286623 & 0.040603 & $-80.9459 \mathrm{I}$ & 0.0000 \\
\hline
\end{tabular}

Regime 3

\begin{tabular}{lrccc} 
C & $-6.68 \mathrm{E}-05$ & 0.000206 & $-0.3242 \mathrm{IO}$ & 0.7458 \\
INTER_FRANC(-I) & 0.063662 & 0.085298 & 0.746357 & 0.4555 \\
LOG(SIGMA) & -5.587430 & $0.059 \mathrm{I} 68$ & $-94.4338 \mathrm{I}$ & 0.0000 \\
\hline
\end{tabular}

Common

\begin{tabular}{lclrr}
\hline AR(I) & -0.288736 & $0.04945 \mathrm{I}$ & -5.838785 & \multicolumn{1}{c}{0.0000} \\
\hline Transition Matrix Parameters & & & & \\
\hline PII-C & 3.378054 & 0.485840 & 6.953023 & 0.0000 \\
PI2-C & $-10.082 \mathrm{IO}$ & $59 . \mathrm{I} 8 \mathrm{I} 62$ & $-0 . \mathrm{I} 70359$ & 0.8647 \\
P2 I-C & -9.967065 & 58.52648 & -0.170300 & 0.8648 \\
P22-C & 4.005338 & 0.554270 & 7.226326 & 0.0000 \\
P3I-C & $-3 . \mathrm{I} 85620$ & 0.547739 & $-5.8 \mathrm{I} 5950$ & 0.0000 \\
P32-C & -3.506297 & 0.525232 & -6.675705 & 0.0000 \\
\hline Mean dependent var & $-3.55 \mathrm{E}-05$ & S.D. dependent var & $0.024 \mathrm{II} 4$ \\
S.E. of regression & $0.024 \mathrm{I} 40$ & Sum squared resid & $0.46794 \mathrm{I}$ \\
Durbin-Watson stat & $2.0274 \mathrm{I} 3$ & Log likelihood & $2968 . \mathrm{I} 47$ \\
Akaike info criterion & -7.262353 & Schwarz criterion & -7.169842 \\
Hannan-Quinn criter. & -7.226842 & & & \\
Inverted AR Roots & -.29 & & & \\
\hline \hline
\end{tabular}


Markov Switching Smoothed Regime Probabilities

$P(S(t)=1)$ : Low Volatility

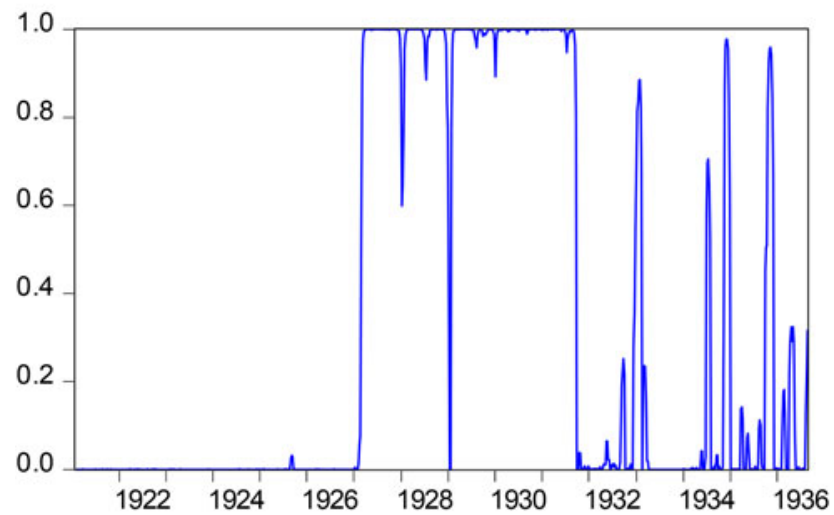

$P(S(t)=2)$ : High Volatility

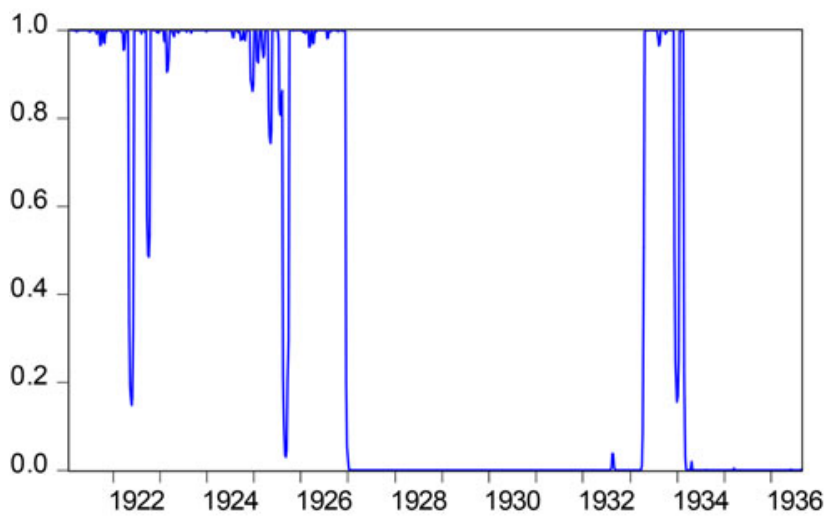

$P(S(t)=3)$ : Intermediate Volatility

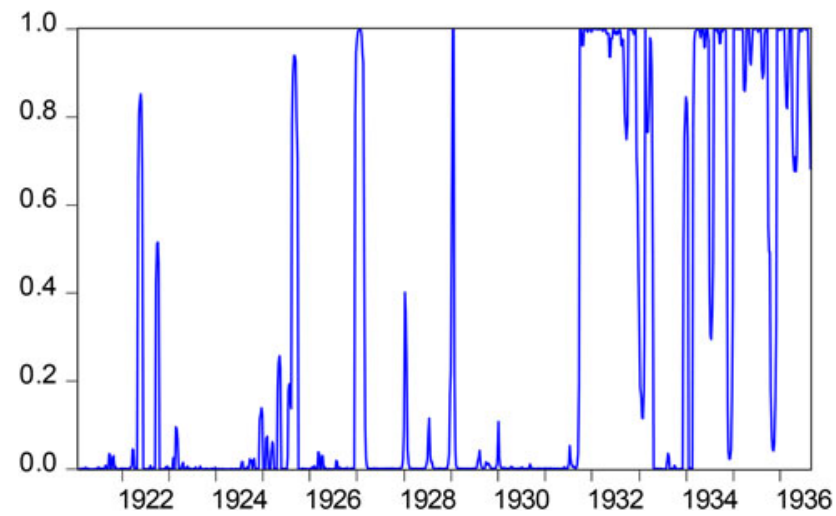

Figure 6. Regime-smoothed probabilities, dollar-franc: weekly data, 1921-36 
that same week the probability of being in the intermediate probability regime had climbed to 0.83 , from almost zero four weeks earlier.

A comparison of Tables 3 and 6 shows that two bilateral exchange rates (dollarpound and dollar-franc) exhibit some similarities, as well as some differences. The most important similarity is that in mid December I933, both the dollar-pound and dollar-franc went through a switch in volatility regime, moving from high to intermediate. This happened while the gold-buying program was still in effect and before Keynes wrote his open letter. Two important differences are: the dates at which volatility switches occur are not the same in the two cases; also, the extent of volatility in the different regimes (as measured by the point estimate of $\log$ (sigma)) is somewhat different across the two exchange rates.

On 30 January I934, and after a heated debate in both chambers of Congress, the Gold Reserve Act of I934 was signed into law. The next day the President set the new official price of gold at $\$ 35$ an ounce, and the Treasury announced that for the foreseeable future it was willing to buy and sell any amount of metal at that price, internationally. Residents of the United States, however, were not allowed to hold gold. This official price of $\$ 35$ an ounce was in effect until August I97I, when President Richard Nixon closed the Treasury's 'gold window'.

A key component of the Gold Reserve Act was the creation of an Exchange Stabilization Fund at the Treasury. ${ }^{42}$ The fund was, to a large extent, tailored after the British Exchange Equalisation Fund, and its main objective was to intervene, under well-defined circumstances, in the global currency markets. The purpose of these interventions was to reduce excessive volatility - something that, as argued, was close to Keynes's heart - and to ensure that the exchange rate would stay within a very narrow window around $\$ 35$ per ounce of gold. The Stabilization Fund was originally funded with $\$ 2$ billion, corresponding to the Federal Reserve profits from the revaluation of the price of gold from $\$ 20.67$ to $\$ 35$ an ounce. ${ }^{43}$

After the passage of the Gold Reserve Act, monetary conditions in the US changed drastically. Between January and December I934 the stock of monetary gold more than doubled; it went from $\$ 3.9$ billion to $\$ 8$. I billion. Part of this increase - a little over $\$ 2.5$ billion - was the result of revaluing the stock of bullion at $\$ 35$ an ounce. But more important than repricing were the large amounts of gold that came into the country immediately after the Gold Reserve Act was passed in late January I934. More than $\$ 750$ million flew in during February alone - \$239 million from London, \$I24 million from Paris - another \$262 million came in during March, and \$I 55 million in April. ${ }^{44}$

42 Section Io (b) of the Act.

43 'Attorney General's opinion on the gold bill', NYT, i 8 January I934, p. I4.

44 Bloomfield (I950) provides a detailed analysis of capital inflows during the interwar period. 
An important question is, how influential was Keynes's letter in the adoption of the Gold Reserve Act? Moggridge (I992 p. 58I) argues that 'the general conclusion seems to be that it [the letter] had little, if any effect'. This view is supported by a letter written by President Roosevelt to Felix Frankfurter on 22 December I933. Here, the President makes a brief reference to 'the professor's' [Keynes's] views on public works, but is completely silent regarding his exchange rate comments. ${ }^{45}$ In a letter to Keynes, written on 17 April I934, Walter Lippmann points out that the letter had influence on the Treasury's decision to purchase long-term government bonds as a way of 'reducing the long-term rate of interest'. In this letter, however, Lippmann does not say a word on exchange rates or gold. ${ }^{46}$

In light of his open letter, why didn't Keynes criticize the Gold Reserve Act, a piece of legislation that rigidly fixed the price of gold? In the New York Times piece he expressly wrote that FDR should reject the temptation to 'devalue the dollar in terms of gold, returning to the gold standard at a new fixed ratio'. A possible answer is that in Keynes's eyes the Gold Reserve Act was not a return to the traditional gold standard. Indeed, under the Act gold was only used to settle international transactions, and could not be held, bought, or sold by American citizens, banks, or corporations. In that regard, the new regime was closer to Keynes's views of a modified gold standard. In an article published in the New Statesman and Nation on 20 January I934, he argued that the official devaluation of the dollar would not harm the UK. However, he wrote, it could have serious implications for the gold bloc countries, whose currencies would now be seriously overvalued. It was possible, he noted, that France would be forced off gold. In spite of this, he provided a positive assessment of the overall situation created by the enactment of the Gold Reserve Act: 'I cannot doubt but that the President's announcement means real progress. He has adopted a middle course between old-fashioned orthodoxy and the extreme inflationist. I see nothing in his policy which need be disturbing to business confidence' (Keynes I982, p. 3 I2). Keynes further believed that as a consequence of the Gold Reserve Act, there would be a monetary conference attended by the US, Great Britain and France. Out of this gathering, he hoped, a new international system with stable, but not totally rigid, exchange rates would emerge. In his New Statesman and Nation article he wrote: '[T] he purpose of a monetary conference would not be to return to an old-fashioned gold standard... [T] he conference would presumably aim for the future not at rigid gold parities, but at provisional parities from which the parties to the conference would agree not to depart except for substantial reasons arising out of the balance of trade or the exigencies of domestic price policy.' 47

45 Roosevelt (I967, p. I83).

46 Keynes (I982, p. 305). In the last section of the open letter Keynes stated that it was very important to lower the long-term interest rate to $2.5 \%$. He suggested that the Federal Reserve 'replace its present short-dated Treasury issues by purchasing long-dated issues in exchange'.

47 Keynes (I982, p. 3I2). In March I934, in a letter to Walter Case, he wondered whether FDR would devalue the dollar further in the next few months. Keynes (I982, pp. 3I-320). 
To summarize: the analysis presented in this article indicates that during the early weeks of the US gold-buying program of I933, exchange rate volatility was very high, as pointed out by Keynes in his open letter. However, the results also unveil two features of this period not mentioned by Keynes. (I) During the gold-buying program volatility was not higher than during other turbulent subperiods in I92 I-36. In that sense, exchange rates may have been 'on the booze' for longer than Keynes pointed out. (2) Towards the latter part of the gold-buying program, exchange rate instability declined significantly, with the system moving decisively from a high-volatility regime to an intermediate-volatility one.

This work may be extended in several directions. For instance, it is possible to use alternative techniques such as EGARCH models. Preliminary results, using that approach, tend to confirm those reported here, in the sense that in the middle of the gold-buying program there was a decline in volatility in both bilateral exchange rates. Another extension would be to move towards even higher-frequency data, focusing on daily exchange rate quotes. A possible shortcoming of that approach, however, is that at that frequency there is additional noise in the data. A third avenue for future research is to try to determine the role of exchange rate 'fundamentals' in currency behavior and volatility during these years. In this case, however, it would be necessary to move to monthly - or even quarterly - data, as data for most fundamentals are only available at those intervals.

Submitted: 6 March 2017

Revised version submitted: 26 June 2017

Accepted: 28 July 2017

First published online: Io November 2017

\section{Sources}

The Jacob Viner Papers. John Seeley Mudd Manuscript Library, Princeton University.

New York Times. Several issues.

\section{References}

ACHESON, D. (1965). Morning and Noon: A Memoir. Boston: Houghton Mifflin.

AHAMED, L. (2009). Lords of Finance: The Bankers who Broke the World. New York: Random House.

BLOOMFIELD, A. I. (I950). Capital Imports and the American Balance of Payments, 1934-39: A Study in Abnormal International Capital Transfers. Chicago: University of Chicago Press.

BLUM, J. M. (1959). From the Morgenthau Diaries: Years of Crisis, 1928-1938, vol. I. Boston: Houghton Mifflin.

BORDO, M. and SINHA, A. (20I6). A lesson from the Great Depression that the Fed might have learned: a comparison of the I932 open market purchases with quantitative easing. Working paper.

DIMAND, R. W. (1994). Irving Fisher's debt-deflation theory of great depressions. Review of Social Economy, 52(I), pp. 92-I07.

EDWARDS, S. (2 I07a). Gold, the Brains Trust and Roosevelt. History of Political Economy, Winter.

EDWARDS, S. (2 I07b), The London Monetary and Economic Conference of 1933 and the end of the Great Depression. Open Economies Review, July.

EDWARDS, S. and SUSMEL, R. (200I). Volatility dependence and contagion in emerging equity markets. Journal of Development Economics, 66(2), pp. 505-32. 
EICHENGREEN, B. (I992). Golden Fetters. Oxford: Oxford University Press.

EICHENGREEN, B. and MITCHENER, K. J. (2004). The Great Depression as a credit boom gone wrong. Research in Economic History, 22, pp. I $83-238$.

EINZIG, P. (1937). The Theory of Forward Exchanges. London: Macmillan.

FELIX, D. (1999). Keynes: A Critical Life. Westport, CT: Greenwood Press.

FISHER, I. (I9I3). A compensated dollar. Quarterly Journal of Economics, 27, pp. $385-97$.

FRIEDMAN, M. and SCHWARTZ, A. J. (1963). A Monetary History of the United States, 1867-1960. Princeton, NJ: Princeton University Press.

GALBRAITH, J. K. (I984). Keynes, Roosevelt, and the complementary revolutions. Challenge, 26(6), pp. $4^{-8}$.

HAMILTON, J. D. (I989). Analysis of time series subject to changes in regime. Journal of Econometrics, 45(I), pp. 39-70.

HAMILTON, J. D. and SUSMEL, R. (I994). Autoregressive conditional heteroskedasticity and changes in regime. Journal of Econometrics, 64(I), pp. 307-33.

HANSEN, B. E. (I992). The likelihood ratio test under nonstandard conditions: testing the Markov switching model of GNP. Journal of Applied Econometrics, 7(SI), pp. S6I-S82.

HANSEN, B. E. (I996). Erratum: the likelihood ratio test under nonstandard conditions: testing the Markov switching model of GNP. Journal of Applied Econometrics, II(2), pp. 195-8.

HARROD, R. F. (I95I). Life of John Maynard Keynes. London: Macmillan.

HAUSMAN, J., RHODE, P. and WIELAND, J. (2016). Recovery from the Great Depression: The farm channel in spring I933. Unpublished paper, University of Michigan.

KEYNES, J. M. (1923). A Tract on Monetary Reform. London: Macmillan.

KEYNES, J. M. (1930). A Treatise on Money. London: Macmillan.

KEYNES, J. M. (I933a). The Means to Prosperity. London: Macmillan.

KEYNES, J. M. (I933b). From Keynes to Roosevelt: our recovery plan assayed. New York Times, 3 I December, section xx, p. 2.

KEYNES, J. M. (1982). Activities 1931-1939, World Crises and Policies in Britain and America, vol. XXI of the Collected Writings of John Maynard Keynes, ed. D. Moggridge. London: Macmillan and Cambridge University Press for the Royal Economic Society.

KROSZNER, R. (I999). Is it better to forgive than to receive? Repudiation of the gold indexation clause in long-term debt during the great depression. Working paper, Center for Research in Security Prices, Graduate School of Business, University of Chicago.

MELTZER, A. H. (2003). A History of the Federal Reserve, vol. I. Chicago: University of Chicago Press.

MITCHENER, K. J. and WEIDENMIER, M. D. (2009). Are hard pegs ever credible in emerging markets? Evidence from the classical gold standard. National Bureau of Economic Research Working Paper no. WI 540 I.

MOGGRIDGE, D. (1992). Maynard Keynes: An Economist's Biography. London: Routledge.

MOLEY, R. (I939). After Seven Years. New York: Harper \& Bros.

MOLEY, R. (1966). The First New Deal. New York: Harcourt.

OBSTFELD, M. and TAYLOR, A. M. (2003). Globalization and capital markets. In Globalization in Historical Perspective. Chicago: University of Chicago Press, pp. I 2 I-88.

O'CONNELL, J. (20I6). On Keynes on inflation and unemployment. European Journal of the History of Economic Thought, 23(I), pp. 82-IOI.

PASVOLSKY, L. (I933). Current Monetary Issues. Washington, DC: Brookings Institution.

RAUCHWAY, E. (20I5). The Money Makers: How Roosevelt and Keynes Ended the Depression, Defeated Fascism, and Secured a Prosperous Peace. New York: Basic Books.

ROOSEVELT, F. D. (1938). Public Papers and Addresses of Franklin D. Roosevelt. New York: Random House.

ROOSEVELT, F. D. (1967). Roosevelt and Frankfurter: Their Correspondence, 1928-1945, annotated by Max Freedman. Boston: Little, Brown.

SKIDELSKY, R. (1992). John Maynard Keynes, vol. II: The Economist as Saviour, 1920-1937. London: Macmillan.

STEIL, B. (2OI3). The Battle of Bretton Woods: John Maynard Keynes, Harry Dexter White, and the Making of a New World Order. Princeton, NJ: Princeton University Press.

SUMNER, S. (1999). The role of the gold standard in Keynesian monetary theory. Economic Inquiry, 37(3), pp. 527-40. 
SUMNER, S. (20I5). The Midas Paradox. Oakland, CA: Independent Institute.

TAVLAS, G. S. (I997). Chicago, Harvard, and the doctrinal foundations of monetary economics. Journal of Political Economy, I05(3), pp. I 53-77.

TEMIN, P. (1976). Did Monetary Forces Cause the Great Depression? New York: Norton.

WARBURG, J. P. (1934). The Money Muddle. New York: Knopf.

WARREN, G. F. and PEARSON, F. A. (I93 I). Prices. New York: Wiley.

WARREN, G. F. and PEARSON, F. A. (I935). Gold and Prices. New York: Wiley.

\section{APPENDIX A: DOLLAR VOLATILITY IN I933, AND THE KEYNES AND WARBURG PLANS}

When Keynes wrote his New York Times letter he already had a clear idea of the type of international monetary system that he wanted to see in place. He had discussed the problem in a number of his writings, including $A$ Tract on Monetary Reform (I923) and $A$ Treatise on Money (1930). But for the purpose of this article the most relevant exposition of Keynes's ideas is the one he presented in the I933 pamphlet The Means to Prosperity, which reproduced in a revised and enlarged fashion four articles published in The Times of London during early $1933 .{ }^{48}$ It is here where he lays down the bases of what would eventually become the 'Keynes Plan' discussed during the Bretton Woods Conference in I944. ${ }^{49}$

In I923, in $A$ Tract on Monetary Reform, Keynes wrote what became a famous quote: 'In truth, the gold standard is already a barbarous relic... [I]n the modern world of paper currency and bank credit there is no escape from a "managed" currency, whether we wish it or not... ${ }^{50}$ However, Keynes's views evolved, and by late $\mathrm{I} 932$ and early $\mathrm{I} 933$ they were more nuanced. ${ }^{51}$ In chapters IV and v of The Means to Prosperity he suggests that all major powers adopt a new standard and create an 'international note issue' linked to gold. These notes would be issued by a new 'international authority', and each country would obtain a quota of these notes in exchange for gold-denominated bonds issued by their governments. ${ }^{52}$ Keynes wrote: 53

$[T]$ he notes would be gold-notes and the participants would agree to accept them as the equivalent of gold. This implies that the national currencies of each participant would stand in some defined relationship to gold. It involves, that is to say, a qualified return to the gold standard.

According to Keynes's plan, central banks would have greater flexibility to undertake countercyclical policies, and the 'gold points' would be widened to 5 percent. ${ }^{54}$ This wider range for the gold points

48 The proposal proper is in chapters IV and $\mathrm{v}$ of the pamphlet.

49 On Bretton Woods and Keynes and Harry Dexter White's confrontations see, for example, Steil (20I3).

50 Keynes (I923, p. I70).

51 In The Means to Prosperity (Keynes I933a) he acknowledged his change in views, when he wrote: 'It may seem odd that I, who have lately described gold as "a barbarous relic", should be discovered as an advocate of such policy ... [G]old has received such a grueling that conditions may be laid down for its future management' (p. 3I).

52 In an appendix to chapter Iv he provided the quotas of gold notes that each of 39 countries would receive, under the assumption that the total issue was restricted to $\$ 5,000,000$.

53 Keynes (I933a, p. 30; emphasis added). The gold notes were a precursor of the Bancor, the international currency he proposed in the I940s. The quotations in this and the next paragraphs are from Keynes (I933a, chs IV and v).

${ }^{54}$ Already in 1932 a number of economists were critical of the Fed for not undertaking countercyclical policy. See Appendix I in Wright (I932). In mid I933 a group of Chicago economists made a more specific proposal for reforming the monetary system, which they sent to the Secretary of Agriculture Henry A. Wallace. This scheme was known as the 'Chicago Plan'. See Tavlas (1997). 
was essential in order to avoid 'wild movements of liquid funds from one international center to another'. The 'international notes' would greatly increase worldwide liquidity, and reduce central bankers' apprehensions about 'free gold', or the amount of bullion over and above what was required to back the bank's monetary liabilities. Keynes also believed that a one-time depreciation of 'national currencies' with respect to gold - notice the plural, 'currencies' - would help increase 'loan-expenditure', as central banks would 'be satisfied with a smaller reserve of international money'. ${ }^{55}$ According to this plan, 'stability of the foreign exchanges... would ensue'. The plan, however, allowed countries to alter their parity with respect to gold under extraordinary circumstances, such as major changes in 'the international price level'. Keynes was clear to point out that these adjustments were extraordinary events; they 'should not be allowed to occur for any other reason [except for major dislocations]'.

Keynes's plan was similar to a plan developed, somewhat independently, in I 933 by James P. Warburg, a banker and adviser to President Roosevelt. In preparation for the London Economic Conference which, as noted, was inaugurated on I2 June I933 - Warburg drafted a proposal for a new 'international standard' to be adopted by all nations. Gold would continue to be at the center of the global system, but the rules of the game would be different. There would be more flexibility and bullion itself would not be physically shipped from place to place. Silver would also have a role; up to 20 percent of central bank reserves could be maintained in the white metal. There would be no gold clauses, which tied debt contracts to the price of gold, and the 'cover ratio' would be reduced significantly in every country. The proposed new cover ratio was 25 percent, which in the US represented an important reduction relative to the existing 40 percent. This 'modified gold standard' would reestablish exchange rate order and would allow exporters, importers, bankers and investors to plan ahead their international businesses. Every country would declare a new parity and exchange rates would be pegged to each other. Competitive devaluation would be ruled out, and with the lower cover ratio central banks would have the ability to undertake expansive monetary policy during downturns, and thus avoid cycles of deflation. ${ }^{56}$

\section{APPENDIX B: DATA SOURCES}

Spot exchange rates: Einzig I937, appendix I.

Forward exchange rates: Einzig I937, appendix I.

World price of gold: Warren and Pearson 1935 , table 9, p. I69.

RFC price of gold: Warren and Pearson 1935 , table 8, p. I68.

55 Keynes (i933a, p. 20).

56 Warburg (I934, pp. I II-I3). On the London Conference, see Edwards (2017b). 